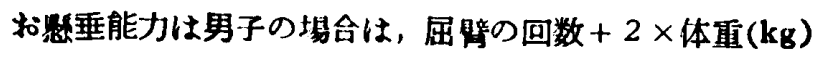

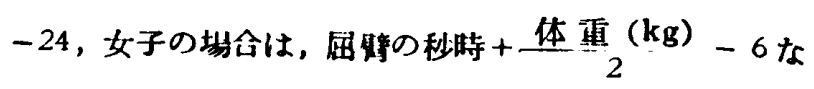

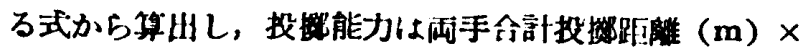
健用パスケットボールの重覃（オンス），100 m 疾走能力

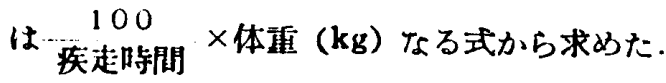

被梌者は熊本短期大学の学生で，男子は492名，女子 は, 91 名である.

\section{伐 粘}

男子の平均僬は指啮 $165.9 \mathrm{~cm}$, 身艮 $1640 \mathrm{~cm}$, 体重 55.8 $\mathrm{cm}$, 胸四 $83.2 \mathrm{~cm}$, 胸左右程 $27.3 \mathrm{~cm}$ ，胸誦後経 $18.1 \mathrm{~cm}$,

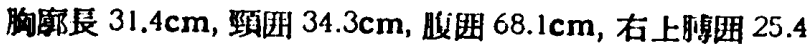

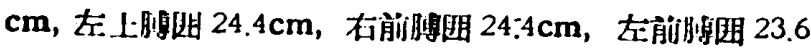
$\mathrm{cm}$, 右上眼最大明 $49.1 \mathrm{~cm}$ ，右下跟最大明 $34.2 \mathrm{~cm}$ ，右握力 $46.6 \mathrm{~kg}$ ，左握力 $43.3 \mathrm{~kg}$ ，背筋力 $146 \mathrm{~kg}$ ，肺活点 $3765 \mathrm{cc}$ ，柔

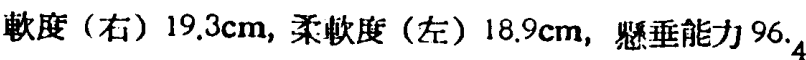
投能力 806.9 , 走能力 384.0 , 跳能力 130.4 ，女子の平均 值怕拾 $154.2 \mathrm{~cm}$ ，身長 $153.6 \mathrm{~cm}$ ，体重 $50.1 \mathrm{~kg}$ ，胸明

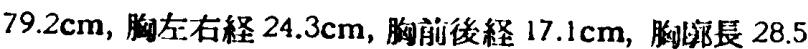

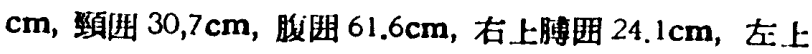

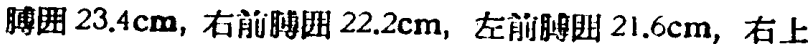
距最大明 $50.7 \mathrm{~cm}$ ，右下跟最大甽 $340 \mathrm{~cm}$ ，右握力 $29.1 \mathrm{~kg}$ ， 左握力 $27.5 \mathrm{~kg}$ ，背筋力 $83 \mathrm{~kg}$ ，椭活年 $2575 \mathrm{cc}$ ，柔軟度(右) $18.9 \mathrm{~cm}$, 柔杴度 (左) $18.5 \mathrm{~cm}$, 照垂能力 45.3 ，投能力 56 1.5 , 走能力 274.3 , 跳能力 89.2 である.

これらの倠のうち，㽖女間に有恐差の認められなかつ た項目は，布下腿最大眀と躯幹柔㳄度で，残りの項目で はいすれれ男女の間に差があると諗奴れた。たよ゙，右 上跟㷅大明は男子よりる女子のうが大きいが，その他の

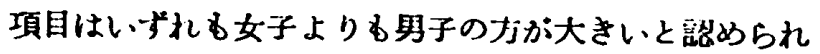

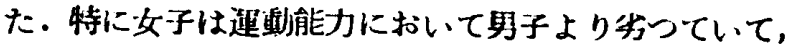

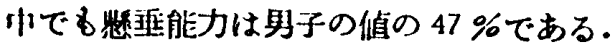

つぎに男女共川学校・高等学校・大学々连畘部に全く 属した事のない者と，それらいる゙れかの時代に遇動部に

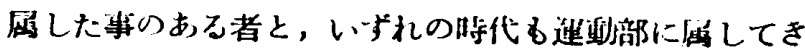
た者とに分けて体格・体力を検榇してみた。

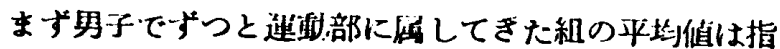

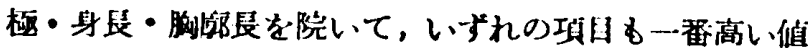

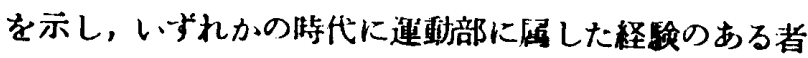
の組の平均値が大体これにつぎ，運動部に全く属した年 のない者の平均值が大体一番近い值を示した。

女子る男子同様の組分けをして検討してみると，ずつ

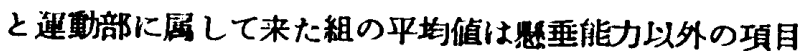
はいずれる一番大きい㑑を示し，いずれかの封代に送動 部に属した経検のある者の組の平均值が大体これにつ
ぎ，連動部に全く捣した事のない者の平均值が一般に。 番低し、值を示した。

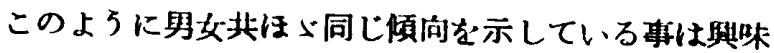
あることの上5に考えられる。

なお，全项目共用女别くに 个ースコアを算山してその 合計を求めてみると，男子の運動部に全く尉した事のな い組の倠は1203，女子のそれは1182，い-゙れかの時代 に属した経呀のある組の男子の值は1251，女子のそれ は1260，ずつと屈してぎた組の男子は1306，女子のそ れは1359 となり，運動部に属してきた者の值が男女共 一潘大きかつた。

各項月の $\mathbf{T}$ ースコアを基準としていわ炏る体力图形の 作彆し，性別・組別に换部しているが，これは紙数の関 保から省略する。

\section{步行に関する研究 I \\ 勾民道路歩行における足䟽の变化}

広蚂大学 竹中匡一，O岩下已伸，松本寿吉

研究目的 われわれは先に「步行に閣子る研究】」と して，正均步行に批りる足跡を計湖して，その場合の足 の问き，すなわち「刉わ」外わ」の傾向と㘳巾につい て発泰した。

ところが，勾配のある坂道の少行では，体の前頙度，

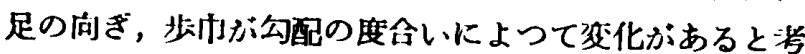
えられる・そこで今回は，勾配道路を步行する際の，足 の间きと步市か，勾配の度合いによつて，どのように积 化するかについて，足䟢の計测結果から考察する。

道路 裙山市水龺町の全長 $220 \mathrm{~m}$ の補装された坂渞 を利用した。 その坂道には，幻配が $0^{\circ}, 5^{\circ}, 10^{\circ}, 15^{\circ}$, $20^{\circ}$ の罚所があり，その地点に石灰をまき計测の地点と した。

测定対象 広岛大学教育学部体育科男子学生 28 名. 测运方法各人は $0^{\circ}$ の地点から，坂道を $20^{\circ}$ の地点 まで登り，200 の地点から $0^{\circ}$ の地点までおりてくる。こ れを 3 回往後させて，各勾䂠の計测地点で足䟢光計测し た。

石灰の上についた足跡の丽足の第 1 指の蹠骨と䟕骨を 絬んた線が，正面に向了線とのなす角度の和をるつて足 の角度とした。それから耐足の蹠骨と蹠骨を結んだ線が

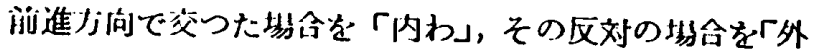
わ」とした。また步巾は後足のかかとと用足のかかとと の距離を测定した。

粘果の考察

足の向きの変化 足向ぎの变化は，登りくだりとる殆 んどのるのが「外わコである。・れを勾配の度合いに上 つて比較して見ると，登りにおい、ては勾倪が急になるに つれて「内わ」のものる「外わコになる傾问がありく 
たりにおいてる同様の㑯问がみられた。

足の角度の变化 足の角度を各勾配に打忊正平均值か らその数化を見ると，登りにおいては $0^{\circ}$ で 8.2?，50で $8.56^{\circ}, 10^{\circ}$ で $10.63^{\circ}, 15^{\circ}$ で $12.72^{\circ}, 20^{\circ}$ で $21.39^{\circ}$ とな つている.これによると足の角度は，公配が $0^{\circ}$ から $15^{\circ}$ まではじよじよに增加しているか，200になると忽激に 增加している。またくだりにおいては，勾唒がけるやか になるにつれて，次第に「外わ」の解が減少してい る. ナたわち, $20^{\circ}$ で $13.77^{\circ}, 15^{\circ}$ で $11.29^{\circ}, 10^{\circ}$ で 9.1 $3^{\circ}, 5^{\circ}$ で $8.60^{\circ}, 0^{\circ}$ で $7.89^{\circ}$ となつていて，200の公配

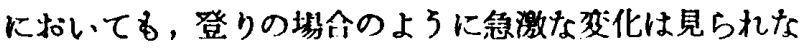
w.

少巾の变化 各勾配に和ける步门の新化を見ると，登

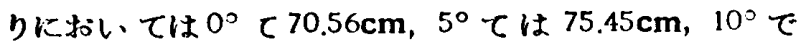
$72.56 \mathrm{~cm}, 15^{\circ}$ で $73.14 \mathrm{~cm}$ となつていて，150までは大

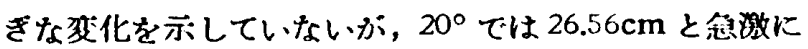
娍少している。またくだりに括いては，200で $46.55 \mathrm{~cm}, 15^{\circ}$ で $69.09 \mathrm{~cm}, 10^{\circ}$ て $71.91 \mathrm{~cm}, 5^{\circ}$ て $71.24 \mathrm{~cm}, 0^{\circ} \tau 69.74 \mathrm{~cm}$ となつていて, $15^{\circ}$ 以下 におい、ては大ぎな放化は見られない、これを话人

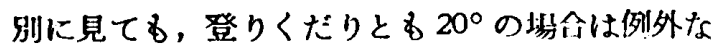
く最小值を示している。

計测の結果から，公足による足の间ぎ，足の㷉 度，步巾の变化を溇察して見たのであるか，これ らはすへて研究目的のところで述べたように，登

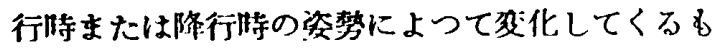
のと苸えられる。

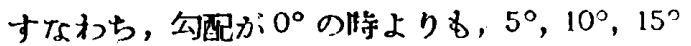

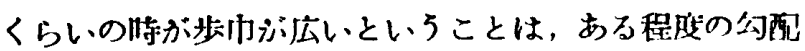
がある萮合に，身体の闹㑯思いきり山来るからてはな

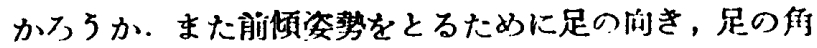

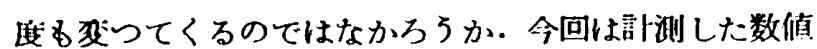
によつてのみ教察したのであるか，今後は步行の枩を 分析することによつて，步行壯の足の间き，足の解陟， 少川小閉題を研究することにする。

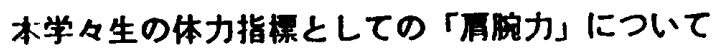
（第二報）

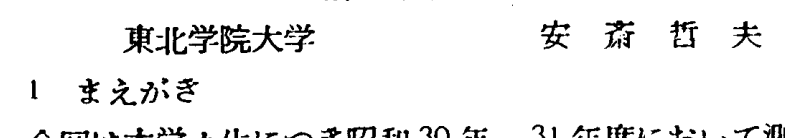

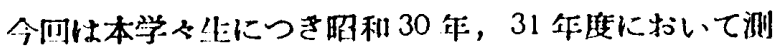
起した「面腕力」を「相阴法」によつて仙の皦力ならび

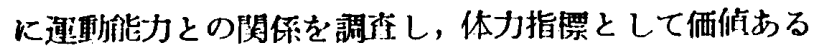
秙果を得たので赫告する。

2 本学々生の房胒力

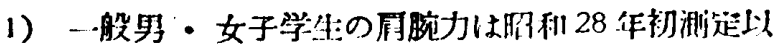
来逐作们上を示しているが，その原因として，正裸体奔
の效果があらわれてきたこと〉，䡛月として主に球投・ 格技を锞したことが举价られると思う。

2) 運動部の䊈日别同腕力

昨年度木学運動部員 18部)について测定した結果を

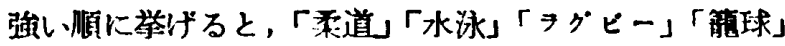
「レスリング」となり，「卓球」山后」「サッカー」は低

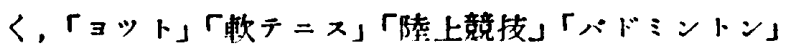
は川間にあるが，2・3の例外を除き何作大なる移動は ないようである。

3 同腕力之背筋力・㨨力

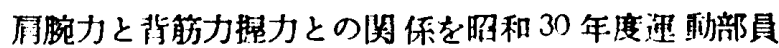
(18 部204名)および 31 年 9 月测芫の一般男于学生 250 名（18才〜25才）について諳梖した結果，背筇力に対し ては両者共に強い順相関がありまた据力に対しても背

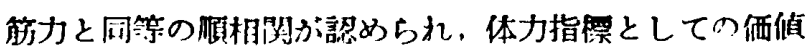
を表わしている。

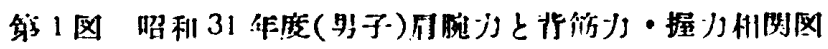

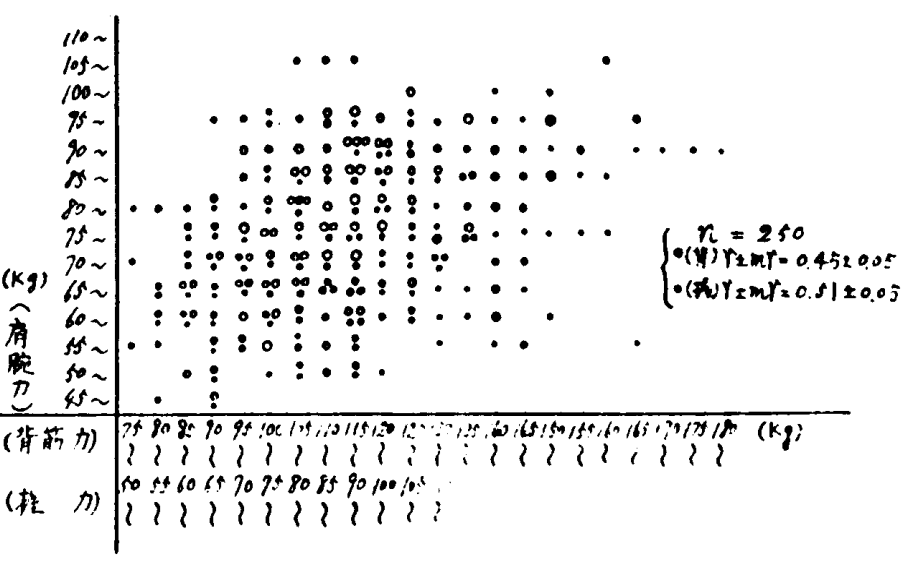

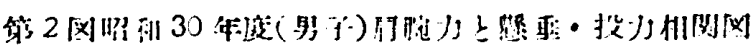

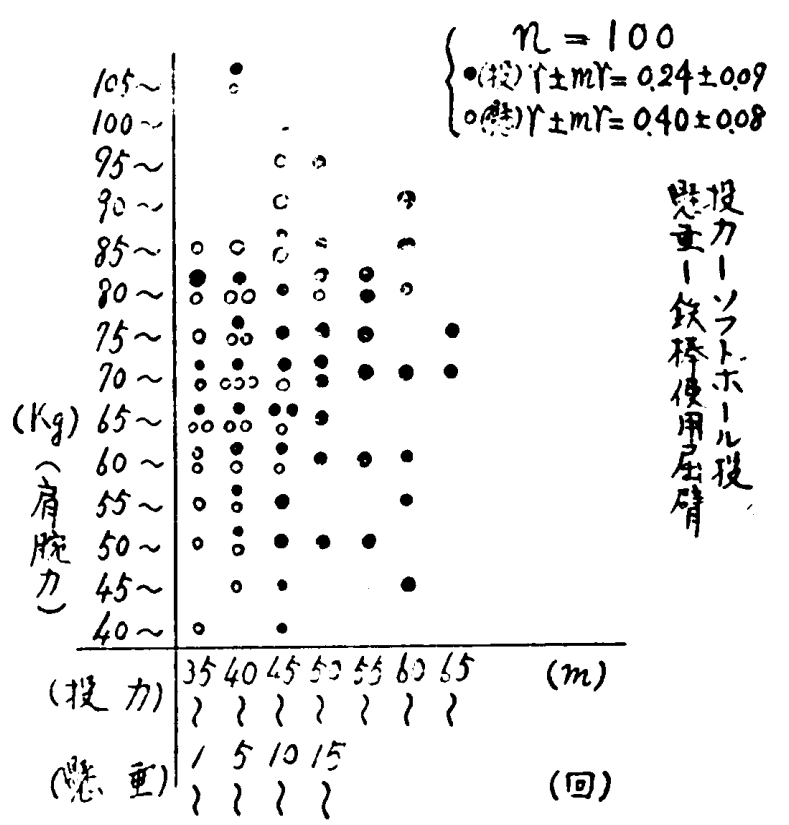

